\title{
Bioavailability of selenium from raw or cured selenomethionine-enriched fillets of Atlantic salmon (Salmo salar) assessed in selenium-deficient rats
}

\author{
Robin Ørnsrud ${ }^{1} *$ and Mette Lorentzen ${ }^{2}$ \\ ${ }^{1}$ Directorate of Fisheries, Institute of Nutrition, Strandgt. 229, P.O. box 185 Sentrum, N-5804 Bergen, Norway \\ ${ }^{2} X$-lab, Ibsensgt. 1045052 Bergen, Norway \\ (Received 21 February 2001 - Revised 6 August 2001 - Accepted 3 September 2001)
}

\begin{abstract}
The bioavailability of Se from raw and cured selenomethionine-enriched (Se-enriched) salmon fillets was assessed in Se-deficient male albino rats (Mol: Wist). A low-Se Torula yeast feed was supplemented with 0, 50,100, 150 or $200 \mu \mathrm{g} \mathrm{Se} / \mathrm{kg}$ as sodium selenite or as Se from raw or cured Se-enriched salmon. The diets were fed to weanling rats for 10 and $30 \mathrm{~d}$. Bioavailability of Se was assessed by metabolic balance, $\mathrm{Se}$ accumulation in femur, muscle, liver and plasma, and induction of Se-dependent glutathione peroxidase (EC 1·11·1.9; GSHpx) in plasma as response parameters. Except for the metabolic balance results, the slope-ratio method was used when calculating Se bioavailability from raw or cured Se-enriched fish fillets (test food) relative to sodium selenite (standard). The data for fractional apparent absorption and fractional retention showed differences $(P<0 \cdot 05)$ among all three Se sources in the order raw salmon $>$ cured salmon $>$ selenite. At $10 \mathrm{~d}$, Se from raw and cured Se-enriched fish fillets tended to be more bioavailable than selenite. This was supported by the observations for Se accumulation in femur and muscle and induction of GSHpx activity. At $30 \mathrm{~d}$, all response parameters showed a higher bioavailability of Se from raw and cured Se-enriched fish fillets compared with selenite. Differences $(P<0 \cdot 05)$ in Se accumulation in muscle at 10 and $30 \mathrm{~d}$, and differences $(P<0 \cdot 05)$ in fractional apparent absorption and fractional retention suggested that curing salmon altered the utilisation of Se. The experimental results showed that enrichment of fish fillets with selenomethionine yields fillets with high Se bioavailability.
\end{abstract}

Bioavailability of selenium: Selenomethionine-enriched salmon: Processed salmon: Selenium

Supplementing selenomethionine (SeMet) to the salmon feed has shown to increase the Se concentration in muscle tissue of farmed Atlantic salmon considerably (Lorentzen et al. 1994). The present study was undertaken to examine the bioavailability of Se from SeMet-enriched (Se-enriched) fish fillets. The term 'bioavailability' describes how efficiently a nutrient in the diet is utilised in a physiological process that is necessary to the organism, i.e. the amount of nutrient that is absorbed and utilised for metabolic function or storage (Fairweather-Tait, 1992). The reported bioavailability of Se from foods varies considerably. In general, the bioavailability of Se from foods of plant origin has been considered more available than Se of animal origin (Combs $\&$ Combs, 1986). However, more recent reports have shown that Se of animal origin may have a higher bioavailability than previously assumed (Shi \& Spallholz, 1994a, $b$; Wen et al. 1997). Fish is known as a rich source of Se with a concentration ranging from 200 to $600 \mu \mathrm{g} / \mathrm{kg}$ wet weight
(Knudsen et al. 1992; Lie et al. 1994). Previous studies with rats have reported a lower bioavailability of Se from fish products than from other Se-containing foods (for example, see Douglass et al. 1981; Alexander et al. 1983). Other more recent reports have shown that $\mathrm{Se}$ from fish has a good bioavailability (Lorentzen, 1990; Knudsen et al. 1992; Wen et al. 1997). Processing methods have been found to enhance the bioavailability of Se (Shi \& Spallholz, 1994a; Shen et al. 1997). Some processing methods may cause protein degradation and thus improve protein digestibility. This may facilitate release of bound Se and therefore increase Se bioavailability (Shi \& Spallholz, 1994a; Shen et al. 1997). However, Se may be lost from the food item through heat processing (Higgs et al. 1972; Eskeland, 1988). Curing of fillets causes breakdown of proteins without the risk of losing Se. 'Gravlaks' (cured salmon) is a traditional Norwegian course where refrigerated salmon fillets are cured over a 2 -d period. Cured salmon was chosen as a

\footnotetext{
Abbreviations: GSHpx, glutathione peroxidase; SeMet, selenomethionine.

* Corresponding author: Dr R. Ørnsrud, fax +47 552380 95, email robin.ornsrud@ nutr.fiskeridir.no
} 
representative of processed fish because the process does not involve heating, it is relatively easy to produce and because the curing process causes breakdown of proteins. The purpose of the present study was thus to establish the bioavailability of $\mathrm{Se}$ from Se-enriched salmon, and to examine the effect of curing on the bioavailability of Se from the Se-enriched fish fillets.

\section{Materials and methods \\ Experimental diets}

The Se-enriched fish fillets were produced in an experiment conducted at the Institute of Nutrition, Directorate of Fisheries, Norway. The experiment produced Atlantic salmon with graded Se levels in muscle tissue through SeMet supplementation. Data on Se speciation from the SeMet supplemented fish are available in an EU report (RIVO - The Netherlands Institute for Fisheries Research, 2000). The Se content of the fillets ranged from 240 , for unfortified tissue, to $610 \mu \mathrm{g} \mathrm{Se} / \mathrm{kg}$ wet weight (corresponding to $800-2050 \mu \mathrm{g} \mathrm{Se} / \mathrm{kg}$ for the dry muscle meal) and were used as Se sources in the experimental diets. Cured salmon was made according to a traditional Norwegian 'gravlaks' recipe: approximately $30 \mathrm{~g}$ of a salt-sugar mixture $(3: 1$, v/v) together with pepper, dill and 1 tablespoon of liquor ('Lord Calvert' whisky) was evenly distributed between two deboned fillets with skin. A pressure of approximately $10 \mathrm{~g} / \mathrm{cm}^{2}$ was provided on top of the fillets. The fillets were kept at $4{ }^{\circ} \mathrm{C}$ for $2 \mathrm{~d}$ and were turned after $24 \mathrm{~h}$. After removing the skin, the cured fillets were treated similar to the raw salmon fillets: each of the salmon fillets was homogenised in a kitchen blender (Dito Sama, Aubusson, France). The homogenised fillets were frozen at $-20^{\circ} \mathrm{C}$, freeze-dried (VirTis Genesis 25SE, New York, USA) and homogenised in a mill (Retsch ZM100, Haan, Germany). The salmon muscle meal was then stored for 1 week at $-30^{\circ} \mathrm{C}$ in plastic bags filled with $\mathrm{CO}_{2}$ to prevent rancidity. A Torula yeast-based feed low in Se (Low Selenium Diet; Ing. Heidenreich A/S, Oslo, Norway) was supplemented with $0,50,100,150$, and $200 \mu \mathrm{g} \mathrm{Se} / \mathrm{kg}$ in the form of sodium selenite or Se from raw or cured salmon (the recommended dietary Se level for growing rats has been estimated to be $150 \mu \mathrm{g} \mathrm{Se} / \mathrm{kg}$; National Research Council (1995)). This provided a total of thirteen experimental diets. The composition of the Torula yeast feed is given in Table 1. A vitamin mixture, a mineral mixture, fish oil (Clupea harengus) and lard (Adeps suillus) were added in amounts sufficient to ensure that the diets contained equal amounts of nutrients and that all diets met the requirements for rats (National Research Council, 1995). The Torula yeast feed was low in vitamin $\mathrm{E}$ and methionine, $60 \mathrm{mg} / \mathrm{kg}$ DL- $\alpha$-tocopheryl acetate and L-methionine equivalent to $0.4 \mathrm{~g} / \mathrm{kg}$ (Sunde et al. 1981) of the Torula yeast feed was therefore added to all diets. The experimental diets were stored at $4{ }^{\circ} \mathrm{C}$ in plastic bags filled with $\mathrm{CO}_{2}$ until fed.

\section{Experimental design}

One hundred and thirty Se-depleted, weanling male albino rats (Mol: Wist; Møllegård, Køge, Denmark) were
Table 1. Composition of the low-selenium basal diet

\begin{tabular}{|c|c|}
\hline & $\mathrm{g} / \mathrm{kg}$ \\
\hline Torula yeast & 300 \\
\hline Sucrose & 590 \\
\hline Tocopherol-stripped lard & 50 \\
\hline Salt mixture (Hubbel, Mendel \& Wakeman) ${ }^{*}$ & 50 \\
\hline ICN vitamin diet fortification mixture† & 10 \\
\hline \multicolumn{2}{|c|}{ 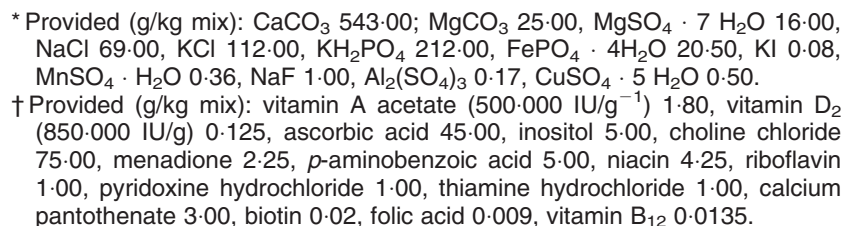 } \\
\hline
\end{tabular}

randomly distributed among thirteen diet groups with ten rats in each group. The rats were housed in individual cages in a temperature- and light-controlled room $\left(21 \pm 2{ }^{\circ} \mathrm{C}, 12 \mathrm{~h}\right.$ light-dark cycle). At $10 \mathrm{~d}$, five rats in each dietary group were killed. The groups given diets 4, 8 and 12 for $30 \mathrm{~d}$ were housed in metabolic cages (Techniplast Gazzada, Buguggiate, VA, Italy). The construction of the metabolic cages allowed for collection of urine and faeces from each rat and made accurate calculation of Se absorption and retention possible. Urine and faeces were collected daily, the samples were accumulated in separate urine and faeces containers for each rat, and stored at $-20^{\circ} \mathrm{C}$. The data on absorption and retention were obtained using the values from the five rats in each diet group. The apparent absorption was calculated as the difference between Se intake and $\mathrm{Se}$ in faeces:

$$
\text { Apparent Se absorption }(\mu g)=\mathrm{Se}_{\text {intake }}-\mathrm{Se}_{\text {faeces }}
$$

The fractional apparent absorption is Se absorption relative to Se intake and was calculated using the formula:

Fractional apparent Se absorption (\%)

$$
=\frac{\left(\mathrm{Se}_{\text {intake }}-\mathrm{Se}_{\text {faeces }}\right)}{\mathrm{Se}_{\text {intake }}} \times 100
$$

Total Se retention is the amount of Se retained in the body after Se excretion. The amount of Se retained was calculated using the formula:

$$
\text { Se retention }(\mu \mathrm{g})=\mathrm{Se}_{\text {intake }}-\left(\mathrm{Se}_{\text {faeces }}+\mathrm{Se}_{\text {urine }}\right)
$$

Fractional retention is total Se retention relative to $\mathrm{Se}$ intake and was calculated using the formula:

Fractional Se retention (\%)

$$
=\frac{\left(\mathrm{Se}_{\text {intake }}-\left(\mathrm{Se}_{\text {faeces }}+\mathrm{Se}_{\text {urine }}\right)\right)}{\mathrm{Se}_{\text {intake }}} \times 100
$$

All rats had free access to ultrafiltered water and were fed ad libitum. Feed spill and leftovers were collected daily and taken into consideration when the feed intake for each rat was calculated. At sampling, the animals were killed by intraperitoneal injection of $0.1 \mathrm{ml}$ Mebumal $(50 \mathrm{mg} / \mathrm{ml}) / 100 \mathrm{~g}$ body weight. Blood was collected from 
the heart using syringes with heparinised needles and chilled on ice until centrifuged at $4^{\circ} \mathrm{C}$ in a cooling centrifuge (Jouan CR312, St. Mazaire, France), at $1300 \mathrm{~g}$ for $10 \mathrm{~min}$. The plasma was transferred to two Eppendorf tubes. One tube was frozen at $-20^{\circ} \mathrm{C}$ for $\mathrm{Se}$ analysis and the other was frozen at $-80^{\circ} \mathrm{C}$ for glutathione peroxidase (GSHpx) analysis. The femoral muscle, femur and liver were dissected, frozen at $-20^{\circ} \mathrm{C}$, freeze-dried, homogenised and kept dry until analysed.

\section{Analytical methods}

The Se content of the diets and tissues was determined by flow injection analysis with hydride generation atomic absorption spectroscopy. Briefly, samples for element analyses $(0.25 \mathrm{~g}$ freeze-dried material or $0.5 \mathrm{ml}$ plasma or urine) were digested in $2 \mathrm{ml} \mathrm{HNO}_{3}$ (Merck, Oslo, Norway) and $0.5 \mathrm{ml} \mathrm{H}_{2} \mathrm{O}_{2}$ (Merck, Oslo, Norway) using a microwave oven (MLS-1200 MEGA, Sorisol, Italy). The digested samples were diluted to a known volume and the Se content determined by hydride generation atomic absorption spectroscopy: Se ions in solution were reduced with $\mathrm{NaBH}_{4}$ (Merck, Oslo, Norway) under acidic conditions, $10 \% \mathrm{HCl}(1.2 \mathrm{M})$ (Merck, Oslo, Norway), and formed volatile Se hydrides (Nakahara, 1995). The hydrides were carried with $\mathrm{Ar}$ as the carrier gas through a $1.0 \mu \mathrm{m} \varnothing$ membrane filter (TE37; Schleicher \& Schuell, Dassel, Germany) to a heated quartz cell where the hydrides dissociated to form free Se atoms. The Se atoms were then quantified by atomic absorption spectroscopy using an external standard curve made from different dilutions of a $1000 \mathrm{mg} \mathrm{Se} / 1$ in $2.5 \% \mathrm{HNO}_{3}(0.3 \mathrm{M})$ stock solution (Teknolab AS, Drøbak, Norway). The analyses were performed using a Perkin Elmer 3300 AAS (Perkin Elmer, Norwalk, CT, USA) coupled with a Perkin Elmer AS 90 autosampler (Perkin Elmer, Ueberlingen, Germany). The 'flow injection system' used was a Perkin Elmer FIAS-200 (Perkin Elmer, Ueberlingen, Germany). Accuracy and precision of the methods were controlled by concomitant analyses of the standard reference materials non-fat milk powder (SRM 1549; National Bureau of Standards, Washington, DC, USA) and bovine muscle (SRM 184; Community Bureau of Reference, Brussels, Belgium). The activity of plasma GSHpx was determined spectrophotometrically in an NADPH-coupled reaction using a slightly modified version of the method described by Flohé \& Günzler (1984). In this assay, GSHpx reduces peroxides using glutathione as an $\mathrm{H}$ donor. Oxidised glutathione is regenerated in an NADPH-coupled reaction catalysed by glutathione reductase. The consumption of NADPH is directly proportional to the consumption of the peroxide, hence it is also proportional to the activity of GSHpx. Briefly, $100 \mu l$ of 1 m Tris-HCl buffer with 5 mm EDTA (pH 8), $20 \mu \mathrm{l}$ of $0.1 \mathrm{M}$ reduced glutathione (Sigma, Oslo, Norway), $100 \mu \mathrm{l}$ of $2 \mathrm{~mm}$ in $0.1 \% \mathrm{NaHCO}_{3}(12 \mathrm{~mm})$ (Merck, Oslo, Norway), $100 \mu \mathrm{l}$ of $10 \mathrm{U} / \mathrm{ml}$ glutathione reductase (Sigma, Oslo, Norway) and $10 \mu \mathrm{l}$ buffer-diluted plasma sample was mixed with $660 \mu \mathrm{l}$ distilled water and incubated at $37^{\circ} \mathrm{C}$ before addition of $10 \mu \mathrm{l}$ of $10 \mathrm{~mm}$ NADPH pre-warmed $t$-butyl hydroperoxide (Aldrich Chemie, Steinheim, Germany). The decrease in NADPH concentration was measured at $37^{\circ} \mathrm{C}$ (Haake $\mathrm{E} 15$ waterbath; Karlsruhe, Germany) and $340 \mathrm{~nm}$ (Shimadzu Graphicord UV-240; Kyoto, Japan). The enzyme assays were performed under conditions where product formation was linear with respect to the amount of protein. Before the GSHpx analyses, the protein concentration of the plasma samples was determined as described by Bradford (1976) using a commercial protein assay (Bio-Rad Laboratory, Richmond, CA, USA). Total lipid content of the diets was measured gravimetrically after extraction with ethyl acetate. Total $\mathrm{N}$ content of the diets was determined in homogenised, freezedried samples as described by Crooke \& Simpson (1971) and protein was calculated as $\mathrm{N} \times 6 \cdot 25$. Ash and $\mathrm{DM}$ content of the diets was determined gravimetrically as described by Mortensen \& Wallin (1989). The carbohydrate content of each diet was calculated as the residue when the amount of water, fat, protein and ash had been subtracted from $1000 \mathrm{~g}$ diet. The energy content of each diet was calculated using Atwater's constants, which gives $17 \mathrm{~kJ} / \mathrm{g}$ protein, $16 \mathrm{~kJ} / \mathrm{g}$ carbohydrate and $36 \mathrm{~kJ} / \mathrm{g}$ fat. The results are summarised in Table 2.

\section{Statistical analyses}

One way ANOVA was conducted for the data on Se intake, apparent absorption, fractional apparent absorption, total retention and fractional retention. A Kolmogrov-Smirnov test was used to assess normality of distribution and homogeneity of variance was tested using Levene's test. All tests were conducted using Statistica ${ }^{\mathrm{TM}}$ Software, Release $4 \cdot 5$ (Statsoft Inc., USA, 1993). A slope-ratio assay (Finney, 1978) was used to compare the bioavailability of Se from raw or cured salmon compared with sodium selenite. In this assay, linear regression lines are generated for both test and standard food and test regression line:standard regression line expresses the relative bioavailability. For a satisfactory application of this method, it is important that the regression lines are linear and that they have a common origin (Finney, 1978). Regression lines are generated when a selected measure of response, e.g. plasma GSHpx activity, is plotted against the Se intake for each rat. A linear dose-response relationship is expected if the following assumptions are fulfilled: (1), the diets contain graded levels of Se; and (2), the Se intake does not exceed the amount required to replete the chosen response parameter. The model also requires that the regression lines intercept at a common origin. A good approximation to this requirement is found when the regression lines converge at 'zero' dose. A basal diet with no Se was therefore used in the generation of all regression lines. The linear regression equations were thus obtained by plotting Se intake against Se concentration in femur, muscle, liver, plasma or GSHpx activity in plasma, and compared using Tukey's test as described by Zar (1996). The ratio of the slopes was calculated manually as described by Finney (1978). The significance level was set at $95 \%$.

\section{Results}

All rats appeared healthy and grew well throughout the experiment. The rats given the basal and selenite diets showed a lower weight gain than the rats given raw or cured 
Table 2. Selenium level, dry matter, fat, protein and ash content, and calculated carbohydrate and energy content of nutrients in the experimental diets*

(Mean values)

\begin{tabular}{lcccccccc}
\hline Se source & Diet no. & $\begin{array}{c}\text { Se level } \\
(\mu \mathrm{g} / \mathrm{kg})\end{array}$ & $\begin{array}{c}\text { DM } \\
(\mathrm{g} / \mathrm{kg})\end{array}$ & $\begin{array}{c}\text { Fat } \\
(\mathrm{g} / \mathrm{kg})\end{array}$ & $\begin{array}{c}\text { Protein } \\
(\mathrm{g} / \mathrm{kg})\end{array}$ & $\begin{array}{c}\text { Ash } \\
(\mathrm{g} / \mathrm{kg})\end{array}$ & $\begin{array}{c}\text { Carbohydrates } \\
(\mathrm{g} / \mathrm{kg}) \dagger\end{array}$ & $\begin{array}{c}\text { Energy } \\
(\mathrm{kJ} / \mathrm{g}) \ddagger\end{array}$ \\
\hline Basal diet & 1 & 17 & 975 & 79 & 143 & 59 & 694 & $16 \cdot 4$ \\
Raw salmon & 2 & 57 & 978 & 76 & 147 & 55 & 699 & $16 \cdot 4$ \\
& 3 & 72 & 979 & 81 & 147 & 56 & 694 & $16 \cdot 5$ \\
& 4 & 97 & 980 & 77 & 153 & 51 & 698 & $16 \cdot 6$ \\
Cured salmon & 5 & 145 & 978 & 79 & 149 & 51 & 699 & $16 \cdot 6$ \\
& 6 & 80 & 978 & 87 & 144 & 55 & 694 & $16 \cdot 6$ \\
& 7 & 95 & 977 & 83 & 145 & 55 & 692 & $16 \cdot 7$ \\
Sodium selenite & 8 & 106 & 978 & 84 & 145 & 53 & 696 & $16 \cdot 6$ \\
& 9 & 139 & 978 & 83 & 136 & 57 & 702 & 16.5 \\
& 10 & 56 & 960 & 75 & 142 & 57 & 686 & $16 \cdot 1$ \\
& 11 & 86 & 960 & 70 & 142 & 57 & 691 & $16 \cdot 0$ \\
& 12 & 119 & 963 & 76 & 145 & 56 & 686 & $16 \cdot 2$ \\
& 13 & 148 & 963 & 75 & 142 & 57 & 688 & $16 \cdot 1$ \\
\hline
\end{tabular}

${ }^{*}$ For details of diets and procedures, see Table 1 and p. 14

†The carbohydrate content of each diet was calculated as the residue when the amount of water, fat, protein and ash had been subtracted from $1000 \mathrm{~g}$ of diet.

‡The energy content of each diet was calculated using Atwater's constants, which gives $17 \mathrm{~kJ} / \mathrm{g}$ protein, $16 \mathrm{~kJ} / \mathrm{g}$ carbohydrate and $36 \mathrm{~kJ} / \mathrm{g}$ fat.

salmon at both 10 and $30 \mathrm{~d}$. The weight gain showed a high correlation to feed intake $(r 0.77$ and $r 0.71)$ whereas the correlation between weight gain and Se intake was $r 0 \cdot 34$ and $r 0.40$ for the rats fed for 10 and $30 \mathrm{~d}$ respectively. Apparent absorption, fractional apparent absorption, total retention and fractional retention were calculated for the rats in metabolic cages given diets 4,8 and 12 which contained 97, 106 or $119 \mu \mathrm{g} \mathrm{Se} / \mathrm{kg}$ as raw salmon, cured salmon or selenite, respectively. The apparent absorption ranged from 29 to $31 \mu \mathrm{g} \mathrm{Se}$, and there were no significant differences among the three diet groups. The fractional apparent absorption ranged from 74 to $81 \%$, and all three diet groups were significantly different from each other $(P<0 \cdot 05)$. The total retention ranged from 14 to $26 \mu \mathrm{g}$, and the raw and cured salmon diet groups were significantly higher than the selenite diet group $(P<0 \cdot 01)$. The fractional retention ranged from 36 to $73 \%$ and all three diet groups were significantly different from each other $(P<0.05)$. The group given salmon retained most and the group given selenite retained least Se. The results are given in Table 3. The relative bioavailability of $\mathrm{Se}$ was assessed by the slope-ratio method using sodium selenite as a reference. Slopes with a coefficient of determination $\left(R^{2}\right)>0.70$ were arbitrarily considered linear. All slopes had $P$ values $<0.001$ for the significance of the regression coefficient (slope $\neq 0$ ). Fig. 1 shows an example of slope-ratio comparison for $\mathrm{Se}$ accumulation in muscle at $30 \mathrm{~d}$. When the regression lines showed a saturation tendency, the data points for the group given the highest dietary level of Se was removed to ensure linearity (femur at $30 \mathrm{~d}$ given selenite and plasma at $30 \mathrm{~d}$ given raw salmon or selenite). At $10 \mathrm{~d}$, the data points for the selenite regression line for plasma GSHpx activity showed an exponential tendency, while at $30 \mathrm{~d}$ a saturation tendency was observed. The data points for the groups given the highest dietary level of selenite at 10 and $30 \mathrm{~d}$ were therefore removed to ensure linearity. Fig. 2 shows the exponential tendency for GSHpx at $10 \mathrm{~d}$ and the saturation tendency for GSHpx at $30 \mathrm{~d}$. There were significant differences $(P<0 \cdot 05)$ in bioavailability among all three Se sources at both 10 and $30 \mathrm{~d}$ as measured by Se accumulation

Table 3. Selenium intake, apparent selenium absorption, fractional apparent selenium absorption (relative to intake), total selenium retention, and fractional selenium retention (relative to intake) for rats in metabolic cages given diets 4,8 and $12^{*}$

(Mean values and standard errors of the mean for five rats per group)

\begin{tabular}{|c|c|c|c|c|c|c|}
\hline \multirow{2}{*}{ Se source... } & \multicolumn{2}{|c|}{ Raw salmon } & \multicolumn{2}{|c|}{ Cured salmon } & \multicolumn{2}{|c|}{$\begin{array}{l}\text { Sodium } \\
\text { selenite }\end{array}$} \\
\hline & Mean & SEM & Mean & SEM & Mean & SEM \\
\hline Se intake $(\mu \mathrm{g})$ & $35 \cdot 6$ & 1.1 & $39 \cdot 8$ & 0.7 & $39 \cdot 0$ & 2.5 \\
\hline Apparent absorption $(\mu \mathrm{g})$ & $29 \cdot 0$ & $1 \cdot 0$ & $31 \cdot 2$ & 0.6 & $29 \cdot 0$ & $2 \cdot 0$ \\
\hline Fractional apparent absorption (\% of intake) & $81 \cdot 5^{\mathrm{a}}$ & 0.7 & $78 \cdot 7^{\mathrm{b}}$ & 0.5 & $74 \cdot 4^{\mathrm{c}}$ & 0.6 \\
\hline Retention $(\mu \mathrm{g})$ & $26 \cdot 0^{\mathrm{a}} \dagger$ & 1.4 & $26 \cdot 2^{\mathrm{a}}$ & 0.6 & $14 \cdot 1^{\mathrm{b}}$ & 1.6 \\
\hline Fractional retention ( $\%$ of intake) & $73 \cdot 4^{a}+$ & $1 \cdot 1$ & $65 \cdot 8^{\mathrm{b}}$ & 0.7 & $35 \cdot 7^{\mathrm{C}}$ & $2 \cdot 3$ \\
\hline
\end{tabular}

a,b,c Mean values within a row with unlike superscript letters were significantly different $(P<0.05)$.

${ }^{*}$ For details of diets and procedures, see Tables 1 and 2, and p. 14.

†Four rats per group due to loss of urine sample. 


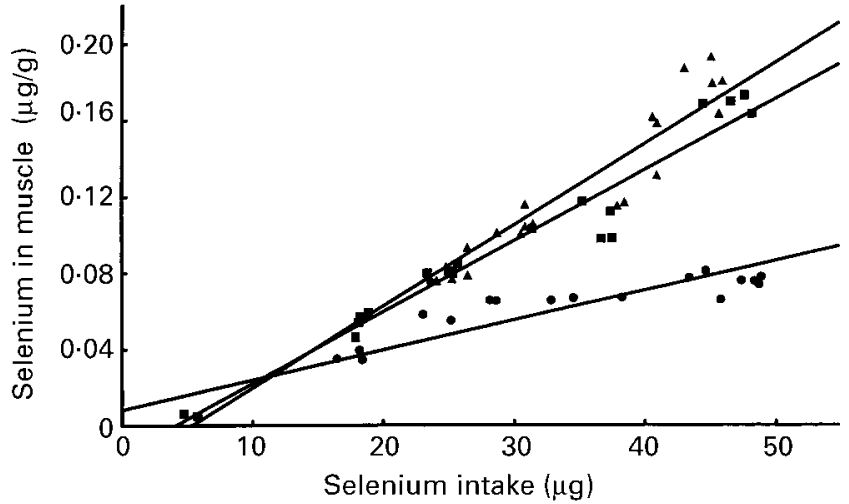

Fig. 1. Example of slope-ratio assay (here given for selenium accumulation in muscle at $30 \mathrm{~d}$ ) for selenium bioavailability in rats given diets with graded levels of selenium from raw salmon (ם), cured salmon $(\mathbf{\Lambda})$ or sodium selenite $(\bullet)$.

in muscle. At $30 \mathrm{~d}$, there were significant differences $(P<0.05)$ between cured salmon and selenite, but not between raw salmon and selenite, as measured by $\mathrm{Se}$ accumulation in liver. At $10 \mathrm{~d}$, Se from raw and cured salmon tended to be more bioavailable than selenite as measured by Se accumulation in femur and induction of GSHpx activity. Se from cured salmon tended to be more bioavailable than Se from raw salmon as measured by Se accumulation in femur and plasma. Se from raw and cured salmon tended to be less bioavailable than selenite as measured by Se accumulation in liver, and Se from raw salmon tended to be less bioavailable than selenite as measured by Se accumulation in plasma. At $30 \mathrm{~d}$, Se from raw and cured salmon tended to be more bioavailable than selenite as measured by induction of GSHpx activity. Se from cured salmon tended to be more bioavailable than $\mathrm{Se}$ from raw salmon as measured by Se accumulation in femur and liver, and Se from raw salmon tended to be more bioavailable than from cured salmon as measured by Se accumulation in plasma. The bioavailabilities of Se from raw and cured salmon relative to selenite at 10 and $30 \mathrm{~d}$ are given in Table 4.

\section{Discussion}

The concept of bioavailability is important when considering the nutritive value of a nutrient in foods. The bioavailability of dietary Se is affected by several factors. The biochemical form of Se and the total protein and fat content of the diet are important in this context. The absorption of Se seems to be higher in high-protein diets than in low-protein diets (Greger \& Marcus, 1981). Further, the fat content and type of fat seem to affect the utilisation of Se (Mutanen \& Mykkänen, 1984). The diets in the present study were therefore designed to be as equal as possible with regard to the protein and lipid content (Table 2). The Seenriched salmon fillets, which contained graded levels of Se, provided a unique possibility of producing isonitrogenous diets with Se levels increasing from approximately 15 to $150 \mu \mathrm{g} \mathrm{Se} / \mathrm{kg}$. The National Research Council (1995) recommends a minimum dietary concentration of $150 \mu \mathrm{g}$ $\mathrm{Se} / \mathrm{kg}$ for growing rats. However, Smith \& Picciano (1987) showed that $250 \mu \mathrm{g} \mathrm{Se} / \mathrm{kg}$ given as SeMet and $500 \mu \mathrm{g} \mathrm{Se} / \mathrm{kg}$

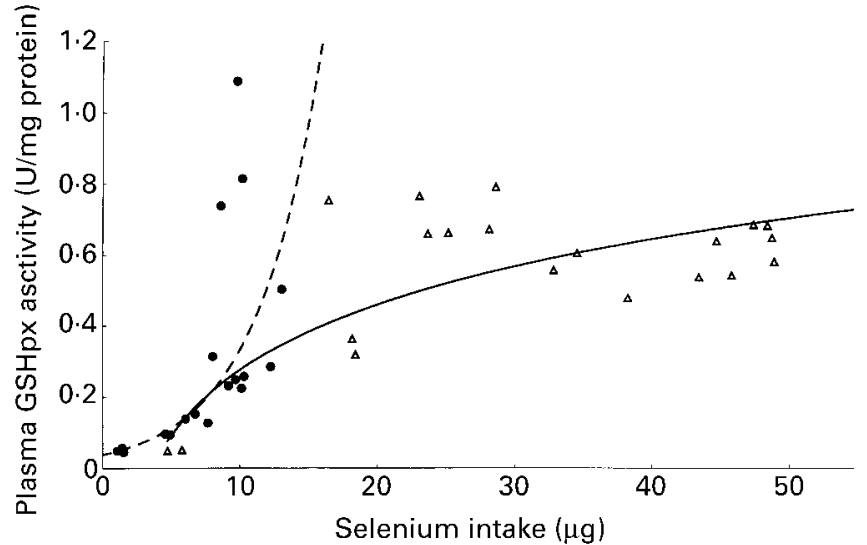

Fig. 2. Induction of plasma glutathione peroxidase (GSHpx; nmol $\mathrm{NADPH} / \mathrm{min}$ per $\mathrm{mg}$ protein) in rats fed the selenite diets for 10 $(\bullet,---)$ and $30(\Delta,-) \mathrm{d}$.

given as sodium selenite was necessary to optimise the activity of GSHpx in tissues in both dams and pups, something that indicates that $150 \mu \mathrm{g} \mathrm{Se} / \mathrm{kg}$ might be too low. In the experimental design used in the present study it was important to keep the dietary Se levels below the requirement to achieve maximum response when the nutrient was fed.

\section{Apparent absorption and total retention of Selenium}

Both fish Se and selenite had a high degree of absorption, something that is in accordance with earlier observations (Whanger et al. 1976; Ringdal et al. 1985; Windisch et al. 1998). The fish used in the present study were enriched with SeMet and most probably contained a relatively high amount of SeMet. SeMet appears to have a higher absorption than selenite (Bopp et al. 1982; Swanson et al. 1991; Windisch et al. 1998) and this may explain why fish Se had the highest fractional apparent absorption. Another possibility is that the differences in fractional apparent absorption are connected with the differences in the concentration of $\mathrm{Zn}$ in the diets. House \& Welch (1989) observed a decreasing absorption of Se with increasing $\mathrm{Zn}$ intake. In the present study, the $\mathrm{Zn}$ concentrations of the sodium selenite diets were slightly higher $(45 \mu \mathrm{g} \mathrm{Zn} / \mathrm{g})$ than the diets with Se-enriched fish $(32 \mu \mathrm{g} \mathrm{Zn/g})$. However, the differences found in the present study were small and probably have little biological relevance. The difference in total retention between the rats given Se from Se-enriched fish and the rats given sodium selenite seemed to be in accordance with the observation that inorganic Se has a higher renal clearance than organically-bound Se (Swanson et al. 1991). Se from fish was more highly retained than sodium selenite and this is in accordance with the findings of Miller et al. (1972); Ringdal et al. (1985); Hassan et al. (1987, 1993).

\section{Organ accumulation of Selenium and induction of glutathione peroxidase in plasma}

The tissue Se accumulations in the rats fed Se-enriched fish were probably partly due to non-specific incorporation of 
SeMet into proteins. This incorporation may be explained mainly by the inability of the protein metabolism to distinguish between $\mathrm{S}$ amino acids and their seleno analogues (Ochoa-Solano \& Gitler, 1968; Behne et al. 1991). Se accumulation should therefore occur in tissues with high methionine content, such as skeletal muscle (Windisch et al. 1998), as was also shown in the present study. Tissue accumulation of Se may be interpreted as a sign of superior bioavailability of SeMet over selenite. However, the level of tissue Se does not adequately measure the physiological Se status of the organism because SeMet is incorporated into general body proteins. The organism does not recognise SeMet as Se and is not able to mobilise Se from tissues containing SeMet (Windisch et al. 1998). However, this tissue SeMet probably serves as an important long-term source of Se as body proteins turn over (Sunde et al. 1981). This is supported by the observations for Se accumulation in liver and plasma: after $10 \mathrm{~d}$, selenite seemed the most available species for synthesis of selenoproteins in the liver. After $30 \mathrm{~d}$, protein turnover seemed to have made more Se from Se-enriched fish available for transformation in the liver, and hence, more retained than selenite.

The hypothesis that processing increases the bioavailability of Se from the Se-enriched fish fillets does not receive unambiguous support from the results for organ accumulation of Se. First, the differences observed for Se accumulation in muscle between raw and cured salmon at day 10 were reversed at day 30. Se accumulation in liver at day 30 showed that cured salmon was more available than selenite, while Se accumulation from salmon did not show significant differences from selenite. It seems evident that the curing process affected Se bioavailability, but the results seem unclear.

The induction of plasma GSHpx activity is probably the most significant parameter of Se bioavailability since it gives an indication of how much $\mathrm{Se}$ is available for biosynthesis of biologically-active selenoproteins. At $10 \mathrm{~d}$, Se from Se-enriched fish tended to be more bioavailable than selenite, as measured by induction of plasma GSHpx. However, the regression curve for selenite at day $10 \mathrm{did}$ not satisfy the self-imposed demand for linearity. To make the curve more linear, the group given the highest dietary level of selenite was removed. If this group had been included, the data points would have shown an exponential tendency (Fig. 2). This shape may be interpreted biologically as a 'delay' in the induction of GSHpx activity. This delay may be explained by the observation that plasma GSHpx has a low priority in Se deficiency (Behne et al. 1995). The regression lines for salmon and 'gravlaks' also seemed to exhibit some delay, but not as clearly as the regression line for selenite. The absence of this delay may be interpreted as a sign of a better bioavailability of Se from Se-enriched fish than selenite. No differences in bioavailability of Se could be traced between raw salmon and cured salmon at 10 and $30 \mathrm{~d}$ however.

At 30 d, Se from Se-enriched fish was more bioavailable than selenite as measured by all response parameters. This suggests that after $30 \mathrm{~d}$, protein turnover has made more Se from SeMet available for synthesis of selenoproteins. Although the results for absorption, total accumulation of 
Se, and Se accumulation in muscle and liver indicated that there were differences in the utilisation of Se from raw salmon and cured salmon, the results for induction of plasma GSHpx activity showed that these Se sources had equal bioavailability.

Thus, the results from the present study indicated that the bioavailability of Se from Se-enriched fish fillets was higher than the bioavailability of selenite. Further, processing of the Se-enriched fish fillets seemed to alter the bioavailability of Se, although no unambiguous conclusions could be reached at this stage. Further work is necessary to clarify the effect of processing on fish fillets with regard to the bioavailability of Se. The present study indicates that enrichment of fish fillets with SeMet yields fish fillets with high Se bioavailability.

\section{Acknowledgements}

The authors wish to thank Amund Måge for comments on the manuscript and Åse Heltveit for technical assistance.

\section{References}

Alexander AR, Whanger PD \& Miller LT (1983) Bioavailability to rats of selenium in various tuna and wheat products. Journal of Nutrition 113, 196-204.

Behne D, Kyriakopoulos S, Scheid S \& Gessner H (1991) Effects of chemical form and dosage on the incorporation of selenium into tissue proteins of rats. Journal of Nutrition 121, 806-814.

Behne D, Weiss-Novak C, Kalklösch M, Westphal C, Gessner H \& Kyriakopoulos A (1995) Studies on the distribution and characteristics of new mammalian selenium-containing proteins. Analyst 120, 823-825.

Bopp BA, Sonders RC \& Westerton JW (1982) Metabolic fate of selected selenium compounds in laboratory animals and man. Drug Metabolism Reviews 13, 271-318.

Bradford MM (1976) A rapid and sensitive method for the quantitation of microgram quantities of protein utilizing the principle of protein-dye binding. Analytical Biochemistry 72, 248-254.

Combs GF \& Combs SB (1986) The Role of Selenium in Nutrition, Orlando, FL: Academic Press.

Crooke WM \& Simpson WE (1971) Determination of ammonium in Kjeldahl digests of crops by an automated procedure. Journal of the Science of Food and Agriculture 22, 9-10.

Douglass JS, Morris VC, Soares JH Jr \& Levander OA (1981) Nutritional availability to rats of selenium in tuna, beef kidney and wheat. Journal of Nutrition 111, 2180-2187.

Eskeland B (1988) Mineraler. Forekomst og tap under ulike matvarefremstillingsprosesser (in Norwegian). InforMat 1, 99-101.

Fairweather-Tait SJ (1992) Bioavailability of trace elements. Food Chemistry 43, 213-217.

Finney DJ (1978) Statistical Method in Biological Assay, 3rd ed., Oxford, London: Alden Press.

Flohé L \& Günzler KA (1984) Assays of glutathione peroxidase. Methods in Enzymology 105, 114-121.

Greger JL \& Marcus RE (1981) Effect of dietary protein, phosphorous and sulphur amino acids on selenium metabolism of adult males. Annals of Nutrition and Metabolism 25, 97-108.

Hassan S, Hakkarainen J \& Lindberg PO (1987) Bioavailability to chicks of selenium in wheat and fish meal. Journal of Veterinary Medicine 34A, 353-363.

Hassan S, Hakkarainen J, Lindberg P \& Sankari S (1993) Response of whole blood glutathione peroxidase and selenium in chicks fed with sodium selenite, wheat and fish meal. Animal Feed Science and Technology 41, 103-111.

Higgs DJ, Morris VC \& Levander OA (1972) Effect of cooking on selenium content of foods. Journal of Agricultural and Food Chemistry 20, 678-680.

House WA \& Welch RM (1989) Bioavailability of and interactions between zinc and selenium in rats fed wheat grain intrinsically labeled with ${ }^{65} \mathrm{Zn}$ and ${ }^{75} \mathrm{Se}$. Journal of Nutrition 119, 916-921.

Knudsen ER, Lorentzen M \& Julshamn K (1992) Biological availability to rats of selenium from cod (Gadus morhua) and selenomethionine relative to sodium selenite. Fiskeridirektoratets Skrifter Serie Ernaring 5, 111-120.

Lie Ø, Lied E, Måge A, Njaa LR \& Sandnes K (1994) Nutrient content of fish and shellfish. Fiskeridirektoratets Skrifter Serie Ernaring 6, 83-105.

Lorentzen M (1990) Fisk som selenkilde - en vurdering av forskjellige formers biologiske tilgjengelighet hos rotter med lav selenstatus (in Norwegian). Cand Scient Thesis, University of Bergen, Norway.

Lorentzen M, Maage A \& Julshamn K (1994) Effects of dietary selenite or selenomethionine on tissue selenium levels of Atlantic salmon (Salmon salar). Aquaculture 121, 359-367.

Miller D, Soares JH, Bauersfeld P \& Cuppett SL (1972) Comparative selenium retention by chicks fed sodium selenite, selenomethionine, fish meal and fish solubles. Poultry Science 51, 1669-1673.

Mortensen AB \& Wallin H (1989) Gravimetric determination of ash in foods: NMKL collaborative study. Journal of the Association of Official Analytical Chemists 72, 481-483.

Mutanen ML \& Mykkänen HM (1984) Effect of dietary fat on plasma glutathione peroxidase levels and intestinal absorption of ${ }^{75}$ Se-labeled sodium selenite in chicks. Journal of Nutrition 114, $829-834$.

Nakahara T (1995) Hydride generation techniques in atomic spectroscopy. Advanced Atomic Spectroscopy 2, 139-178.

National Research Council (1995) Nutrient Requirements for Laboratory Animals, Washington, DC: National Academy Press.

Ochoa-Solano A \& Gitler C (1968) Incorporation of ${ }^{75} \mathrm{Se}-$ Selenomethionine and ${ }^{35} \mathrm{~S}$-Methionine into chicken egg white proteins. Journal of Nutrition 94, 243-248.

Ringdal O, Bjørnestad EØ \& Julshamn K (1985) Comparative utilisation of fish selenium and inorganic selenite by rats of normal selenium status. Annals of Nutrition and Metabolism 29, 297-305.

RIVO - The Netherlands Institute for Fisheries Research (2000) Speciation and bioavailability of selenium from processed and tailor-made fishery products, pp 3-23 EU FAIR Project CT95 0771, Wageningen, Wageningen UR.

Shen LH, Hook-van Nieuwenhuizen M \& Luten JB (1997) Speciation and in vitro bioavailability of selenium in fishery products. In Seafood from Producer to Consumer, Integrated Approach to Quality, pp. 653-663 [JB Luten, T Borreson and J Oehlensclager, editors]. Amsterdam: Elsevier Science B.V.

Shi B \& Spallholz JE (1994a) Bioavailability of selenium from raw and cooked ground beef assessed in selenium-deficient Fischer rats. Journal of the American College of Nutrition 13, 95-101.

Shi B \& Spallholz JE (1994b) Selenium from beef is highly bioavailable as assessed by liver glutathione peroxidase (EC 1.11.1.9.) activity and tissue selenium. British Journal of Nutrition 72, 873-881.

Smith AM \& Picciano MF (1987) Relative bioavailability of seleno-compounds in the lactating rat. Journal of Nutrition 117, $725-731$.

Sunde RA, Gutzke GE \& Hoekstra WG (1981) Effect of dietary 
methionine on the biopotency of selenite and selenomethionine in rat. Journal of Nutrition 111, 76-86.

Swanson CA, Patterson BH, Levander OA, Veillon C, Taylor PR, Helzlouer K, McAdam PA \& Zech LA (1991) Human $\left[{ }^{74} \mathrm{Se}\right]$ selenomethionine metabolism: a kinetic model. American Journal of Clinical Nutrition 257, R556-R567.

Wen HY, Davis RD, Shi B, Chen JJ, Chen L, Boylan M \& Spallholz JE (1997) Bioavailability of selenium from veal, chicken, beef, pork, lamb, flounder, tuna, selenomethionine, and sodium selenite assessed in selenium-deficient rats. Biological Trace Element Research 58, 43-53.
Whanger PD, Pedersen ND, Hatfield J \& Westvig PH (1976) Absorption of selenite and selenomethionine from ligated digestive tract segments in rats. Proceedings of the Society of Experimental Biological Medicine 153, 295-301.

Windisch W, Gabler S \& Kirchgessner M (1998) Effect of selenite, seleno cysteine and seleno methionine on the selenium metabolism of ${ }^{75} \mathrm{Se}$ labeled rats. Journal of Animal Physiology and Animal Nutrition 78, 67-74.

Zar J (1996) Biostatistical Analysis, 3rd ed., Upper Saddle River, NJ: Prentice-Hall International. 